\title{
Adapting to climate change: Assessing the vulnerability of ecosystem services in Europe in the context of rural development
}

Article type:

Title:

Authors:

Affiliations:

Address for correspondence:
Original article

Adapting to climate change: Assessing the vulnerability of ecosystem services in Europe in the context of rural development

Tzilivakis, J., Warner, D.J., Green, A. and Lewis, K.A.

Agriculture and Environment Research Unit (AERU), School of Life and Medical Sciences, University of Hertfordshire, United Kingdom.

Dr John Tzilivakis, Agriculture and Environment Research Unit (AERU), School of Life and Medical Sciences, University of Hertfordshire, United Kingdom. AL10 9AB. Email: J.Tzilivakis@herts.ac.uk

Tzilivakis, J., Warner, D., Green, A. \& Lewis, K.A. (2015) Adapting to climate change: Assessing the vulnerability of ecosystem services in Europe in the context of rural development. Mitigation and Adaptation Strategies for Global Change, 20(4), 547-572 


\section{Abstract}

Over the past decade, efforts to move towards a low carbon economy have been increasingly coupled with the acknowledgement that we also need develop climate resilient economies, capable of adapting and responding to changes in climate. To shift society in these directions we need to quantify impacts in relation to these objectives and develop cost-effective interventions. Techniques for quantifying greenhouse gas emissions are relatively well established and enable identification of hotspots where there is emissions reduction potential. However, there are no established techniques to assess and quantify adaptation vulnerability issues and identify hotspots for intervention. This paper presents work undertaken at a European level with the objective of identifying potential hotspots where ecosystem services may be vulnerable to climate change and thus where intervention may be required under the European Rural Development Programme. A pragmatic and relatively simple approach is presented, based on data that is readily available across Europe. The vulnerability assessments cover: Water (quality: dilution and filtration, regulation: flooding and provision); Soils (erosion and organic matter); and Biodiversity (forest fires, migration and pollination). The framework and assessments presented are considered fit for purpose (at a basic level) and they are potentially valuable tools for targeting limited resources to achieve desirable outcomes. They also contribute towards providing a better understanding of the climate change challenges we face and support the formulation of solutions to optimally address those challenges. There is scope to further improvement and a number of options are discussed and explored within this paper.

Keywords: adaptation; adaptive capacity; climate change; ecosystem services; rural development; vulnerability 


\subsection{Introduction}

\subsection{Background and objectives}

Since the 1970's the issue of anthropogenic induced climate change has steadily risen up the political agenda resulting in the emergence of government regulations and interventions that aim to steer society in a more climate friendly direction towards a low carbon economy. This is now coupled with the acknowledgement that, as well reducing the concentration of atmospheric greenhouse gases (GHGs), we need to develop climate resilient economies, capable of adapting and responding to the changes in climate that do occur. The process of implementing regulations and interventions has largely been specific regulations to tackle emissions or address adaptation issues. These still exist but are now coupled with a process of mainstreaming climate change objectives (mitigation and adaptation) into other policies, for example the European Union (EU) Common Agricultural Policy (CAP), and specifically pillar 2 of the CAP on rural development. In process of developing rural development programmes (RDPs) for the next programming period (2014-2020), there is an opportunity to incorporate climate change objectives and consequently develop measures and operations that tackle these objectives alongside other rural development issues. Techniques for quantifying GHG emissions and potential reductions are relatively well established and enable identification of hotspots where there is emissions reduction potential. However, there are no established techniques to assess and quantify adaptation issues and identify hotspots for intervention.

This paper presents work undertaken at a European level where the objective was to develop a framework to assess the potential of rural development measures and operations for improving the adaptive capacity of ecosystem services. It focuses on the vulnerability risk assessment that was undertaken as part of this project in order to help identify potential 'hotspots', where ecosystem services may be vulnerable to climate change and thus where intervention may be required to increase the adaptive capacity. The work focuses on ecosystem services and their ability to adapt to climate change, with an emphasis on physical aspects, where clear RDP interventions could be made to address issues. However, it is important to acknowledge that there can also be socio-economic impacts and vulnerabilities. These largely fall beyond the scope of the work undertaken within this study, although they are not disconnected as, for 
example, rural development funds may be used to invest in infrastructure to boost the adaptive capacity and resilience of regions, including ecosystem services within those regions. For example, investments in farm waste structures may reduce pollutant loads and thus impact upon water quality dilution ecosystem services. Such investments can boost the financial capacity of a region to adapt, while also addressing environmental and ecosystem service issues.

An important aspect to the work undertaken was that it had to be pragmatic in the context of developing rural development programmes and operations. In an ideal world we would collect all the data needed to undertake the most scientifically robust and credible assessment possible. However, such data can be extremely costly to collate and thus in many instances does not exist, yet policies and programmes are still required to address the issues society faces. Consequently in many instances the work has involved simple pragmatic approaches using readily available/existing data sources. This inherently introduces limitations to the study and the use of its results. These limitations are reviewed in the discussion.

The landscape of climate change programmes, policies and strategies is outlined below to illustrate the evolution in societal understanding and responses. This is accompanied by a review of recent studies and literature on climate change adaptation, resilience, adaptive capacity and vulnerability, the linkages between them and the various approaches to metrics to aid assessments. This forms the basis for the approach taken to the vulnerability assessment presented herein.

\subsection{A brief history of climate change programmes, policies and strategies}

In 1979 evidence of the negative effects of human activity on climate were presented at the first World Climate Conference in Geneva (WMO, 1979). This was followed by the establishment of the Intergovernmental Panel on Climate Change (IPCC) to assess scientific, technical and socio-economic information relevant for the understanding of climate change, its potential impacts and options for adaptation and mitigation. In 1990, the First Assessment Report of the IPCC (IPCC, 1990) confirmed that human-induced climate change is a threat and 
the UN General Assembly formally launched negotiations on a convention, resulting in the UN Framework Convention on Climate Change (UNFCCC) in 1992. This was followed by the Kyoto Protocol in 1997, in which the then EU-15 agreed to reduce collective emissions during 20082012 to 8\% below 1990 levels. The UN Climate Change Conference in Durban, South Africa in 2011 agreed to maintain existing commitments and to negotiate a new regime by 2015 and steps were taken towards a new global climate agreement at the Doha conference $\left(18^{\text {th }}\right.$ session of the Parties to the UNFCCC and the $8^{\text {th }}$ session of the of the Parties to the Kyoto Protocol) in 2012.

Since the 1990 's the main emphasis of these initiatives has been reduction in the emissions of greenhouse gases (GHGs). However, in the last 10 years there has been increasing recognition that measures to reduce emissions need to be accompanied by action to adapt to the consequences of climate change. This is apparent in the European Commission's seventh Environment Action Programme that was published in 2012 (EC, 2012). Alongside emissions reduction, adaptation to climate change is one of the programme's key features, as it is linked to many other issues on the environmental agenda such as sustainable land use, urban environment, sustainable food, protecting water and the marine environment. In April 2013, the Commission adopted an EU Strategy on Adaptation to Climate Change (EC, 2013).

\subsection{Adaptation, resilience, adaptive capacity and vulnerability}

Assessing adaptation issues and developing policies and interventions to enhance the ability of a region to adapt to climate change is a complex and dynamic issue. It involves developing an understanding of the resilience, adaptive capacity and vulnerability of our environmental and socio-economic systems, i.e. their ability to perform their functions, meeting the needs of current and future generations, when faced with perturbations such as climate change.

Resilience, adaptive capacity and vulnerability are emergent properties of a complex system and so are not directly measureable. Consequently assessing potential impacts and vulnerabilities is difficult. Additionally, as Engle (2011) highlights with respect to resilience, in its strict definition (the ability of a system to return to a single stable equilibrium) may actually be a negative property in some circumstances, and what is actually needed is the ability to 
adapt, which may involve a shift in the system to a new equilibrium. For example, the resilience of cropping systems that require certain amount of water could be enhanced through more efficient irrigation practices when water is scarce (i.e. yield maintained despite fluctuating water availability), but what may be required is adaptation to cropping systems that fundamentally require less water, but maintain yields - the new equilibrium is crop production with lower water consumption. There may also be instances where the shift in the system is desirable, for example there is some evidence to suggest that the Sahara desert may be greening due to increased rainfall as a consequence of climate change (Owen, 2009). It is a question of the system being able to perform desired functions and ecosystem services, and thus have the capacity to adapt to continue to provide desired functions and services when faced with pressures such as climate change. The vulnerability (risk to) these ecosystem services is a "function of the character, magnitude, and rate of climate variation to which a system is exposed, its sensitivity, and its adaptive capacity" (Houghton et al., 2001; McCarthy et al., 2001). Adger (2006) also highlights that the absence of capacity to adapt also increases vulnerability. Thus 'adaptive capacity', the ability of a system to prepare for stresses and changes in advance or adjust and respond to the effects caused by stresses, forms a key intervention point to assess and enhance adaptability and reduce vulnerability (Vincent, 2007). In the context of climate change, Engle (2011) outlines how increasing adaptive capacity improves the opportunity of systems to manage varying ranges and magnitudes of climate impacts, while allowing for flexibility to rework approaches if deemed at a later date to be on an undesirable trajectory.

In the context of developing programmes, policies and interventions to address climate change objectives, with regard to mitigation of GHG emissions there are relatively well established scientific techniques. Concentrations of GHGs in the atmosphere can be measured and monitored, GHG emission sources can be directly measured and we can derive emission factors to model emissions, likewise we can measure carbon sequestration and derive sequestration factors and models. There are clear units for these measures, i.e. tonnes of carbon or carbon dioxide equivalents $\left(\mathrm{tCO}_{2} \mathrm{e}\right)$. However, with respect to adaptation, adaptive capacity, resilience and vulnerability, there are no units of measurement and it is not directly measureable. This 
presents a challenge to overcome if we are to be able identify hotspots where adaptation to climate change may be an issue and to able to quantify the potential impact of interventions and thus determine and prioritise those which are most cost-effective.

\subsection{Metrics of adaptation, adaptive capacity and vulnerability}

Several attempts have been made to develop metrics of adaptation, adaptive capacity and vulnerability. A common approach in recent years is the use of indices. For example, O'Brien et al. (2004) developed a measure of adaptive capacity based on a composite of biophysical, social, and technological indicators and applied it to districts in India. More recently, a similar approach was undertaken for Europe as part of the ESPON programme (ESPON, 2012) in the context of the impact of climate change on territorial cohesion. This work involved assessing adaptive capacity, by calculating a weighted combination of economic capacity, infrastructural capacity, technological capacity, knowledge and awareness and institutional capacity, with the weights being based on a Delphi survey of the ESPON Monitoring Committee. This resulted in a map of Europe showing the overall capacity to adapt to climate change for each NUTS3 (Nomenclature d'Unités Territoriales Statistiques) region.

These are relatively high level assessments and are thus quite generic, as was their intended purpose, i.e. to provide a broad overview. It is possible to develop less generic approaches, which usually comes down to the choice of indicators. For example, Swanson et al. (2009) developed indicators of adaptive capacity for agriculture in the prairie region of Canada, focusing on six areas: economic resources; technology; information, skills and management; infrastructure; institutions and networks; and equity. Similar work has also been undertaken in Australia (Brown et al., 2010; Nelson et al. 2010a \& b, 2007) which drew upon the concepts of human, social, natural, physical and financial capital developed by Ellis (2000) to develop an adaptive capacity index. Schröter et al. (2004) developed a spatially explicit generic macroscale index of adaptive capacity based on six determinants which were identified by the IPCC (IPCC, 2001): power, flexibility, freedom, motivation, knowledge and urgency.

Many of these studies (e.g. Brown et al., 2010; EPSON, 2012; Nelson et al. 2010a \& b, 2007) have only developed a generic/single metric for the adaptive capacity of a region. These are 
often overlaid with climate change projections to provide an assessment of vulnerability. For example, EPSON (2012) combined regional potential impacts of climate change with the regional capacity to adapt to climate change to produce the vulnerability map.

Some have taken this concept further and overlaid these adaptive capacity indices with impacts on ecosystem services. For example, Schröter et al. (2004) combined ecosystem models with global change scenarios to identify potential changes in ecosystem services. Socio-economic indicators were combined with global change scenarios to derive maps of changes in adaptive capacity, and then these two outputs were combined to produce vulnerability maps. Natural England (2011) extended this concept further and assessed the biophysical vulnerability of key biodiversity assets to climate change in England. In this study adaptive capacity was based on the assumption that permeable, topographically heterogeneous landscapes, with a greater number of soil types and land cover diversity, will have a greater adaptive capacity to climate change. It was then quantified by measuring the extent of ecological networks to give an estimate of permeability; variation in height to give an estimate of topographic heterogeneity; the number of different soil types to give an estimate of soil diversity; and land cover dominance to give an estimate of land cover diversity. Adaptive capacity was then combined with climate change projections and habitat sensitivity data to produce a vulnerability assessment, for example, the vulnerability of upland heath areas in England.

Despite the studies reviewed above, a consistent and established approach to measuring and assessing adaptation, adaptive capacity and vulnerability is yet to emerge. What is apparent is that the approach taken is often driven by the data available, as opposed to defining a method and then gathering the necessary data. This is largely to due to the cost and practicalities of collecting data over large areas. In the studies above, many of the indicators used were already being recorded at national or regional levels, and some were bespoke to those regions and consequently not easily transferable to other countries or regions. Therefore data availability with the EU-27 was a key driver in the vulnerability assessment presented herein. A pragmatic approach was required to utilise existing data sets to generate the assessments necessary to tackle the issue of adaptation climate change. 


\subsection{Vulnerability assessment}

\subsection{Methodology}

\subsubsection{Overview}

The work described below draws upon many of the ideas and concepts outlined above. A risk assessment approach has been taken by combining data on sensitivity with data on exposure (i.e. in this instance projected changes in climate). A key issue for this work was to utilise data that was readily available for all the EU-27 Member States. There was no scope to identify and collect new data for this assessment. Consequently, this resulted in a relatively simple approach with respect to the data involved and how it was combined for the risk assessment.

With regard to climate change data, there are many climate change projection models and data sets (Christensen et al., 2011; ESPON, 2012; Semenov and Stratonovitch, 2010). The vulnerability assessments could be calculated using a variety of climate change models and projections. However, in this instance the ESPON data set (ESPON, 2012) was deemed suitable, firstly because it was readily available for the EU-27 and secondly because it was in a suitable spatial format. The climate parameters included projected:

- Decreases and increases in winter and summer rainfall

- Increases in the number of days with heavy rainfall

- Increases in run-off

- Increases in mean annual temperature

These parameters are outputs from the climate model COSMO-CLM (CCLM) (Rockel et al., 2008) averaged over models runs (Climate of the 20th Century (run no.1 and 2) and Scenario A1B (run no.1, 2 and 3)), time periods (1961-1990, 2071-2100). They have then been aggregated to European NUTS3 regions by share of cell coverage of regional area. The aggregation to NUTS3 regions does reduce the resolution of the outputs. A $1 \mathrm{~km}$ or $10 \mathrm{~km}$ grid resolution for the climate data would have been better, but this was not available. However, the NUTS3 resolution was considered to be acceptable for the purposes of this study. Further 
details on the COSMO-CLM model and all the parameters used are available from the CLMCommunity (2013).

With regard to ecosystem services, there are numerous and multiple classifications (Balmford et al., 2011; de Groot et al., 2002; Haines-Young and Potschin, 2010; McInnes et al., 2008; MEA, 2003). The vulnerability assessment focuses on those services which are likely to be sensitive to climate change and for which data are readily available for the EU-27. These criteria were used to scope down the number of services to be assessed and also meant that in some instances (due to data availability) a simplistic approach was necessary. Additionally, in some instances the ecosystem services explored may be viewed more as impacts due to the nature of the data available, but there are inherent connections to ecosystem services. For example, soil erosion is not an ecosystem service itself, but the regulation of soil erosion and the provision of soil are ecosystem services. The scoping and simplification process resulted in the classification of services into Water, Soils and Biodiversity (see Table 1 ) representing the 3 key areas within the EU priorities for rural development (Priority 4, EC, 2011). The assessment of other ecosystem services could be developed in the future should data become available. There is also scope to combine the outputs from the key services shown in Table 1 to assess other services. For example, the outputs from the forest fires, water provision and soil erosion vulnerability assessments could be combined to assess potential impacts on landscape (thus covering aesthetic and recreational ecosystem services). 
Table 1: Key ecosystem services assessed

\begin{tabular}{|c|c|c|}
\hline Category & Service & Description \\
\hline \multirow[t]{4}{*}{ Water } & Quality: Dilution & Dilution of pollutants in surface waters. \\
\hline & Quality: Filtration & Filtration of pollutants in surface waters. \\
\hline & Regulation: Flooding & $\begin{array}{l}\text { The regulation of water to prevent } \\
\text { flooding, e.g. attenuation of flood peaks }\end{array}$ \\
\hline & Provision & The provision of water for human use. \\
\hline \multirow[t]{2}{*}{ Soils } & Erosion & $\begin{array}{l}\text { The regulation of soil erosion processes to } \\
\text { reduce loss of productive land. }\end{array}$ \\
\hline & Organic matter & $\begin{array}{l}\text { The protection and increase of soil organic } \\
\text { matter to aid soil protection, fertility and } \\
\text { other services. }\end{array}$ \\
\hline \multirow[t]{3}{*}{ Biodiversity } & Forest fires & The regulation/prevention of forest fires. \\
\hline & Migration & $\begin{array}{l}\text { The ability of wildlife and biodiversity to } \\
\text { migrate to adapt changing climate. }\end{array}$ \\
\hline & Pollination & $\begin{array}{l}\text { The population of pollinators and their } \\
\text { ability to pollinate agricultural crops. }\end{array}$ \\
\hline
\end{tabular}

Spatial data on climate change and ecosystem services were imported into ArcGIS and converted into a raster format. The datasets were then re-classed, i.e. converting the units of the original datasets into integer classes (see below for further details). This enabled the use of the 'map algebra' tool (within the Spatial Analyst tool of the ArcGIS toolbox) to mathematically combine the data, using the equations presented below, to calculate/assess vulnerability of each ecosystem service. The results are presented in the form of maps showing the spatial distribution of vulnerability classes across the EU-27.

The climate projection data outlined above have been linearly re-classed as shown in Tables 2 and 3. The re-classing and equations used for each assessment are outlined below and resulting vulnerability maps are presented in the results section. In many instances the reclassification is a simple linear classification, but in other instances the classification follows 
categories used by the original authors of the data in order to ensure consistency in approach with other projects. The classes that result from both the reclassification and the various equations (presented below) do not have any units. They are simply a numerical scale of relative vulnerability. The results of each vulnerability assessment have different ranges of vulnerability classes. It would be possible to normalise the class ranges, e.g. onto a scale of 0 to 100 , however this would be meaningless and could also be misleading, as it would imply some equivalency in vulnerability across the different assessments, when this is not the case. Each assessment should be viewed individually and a vulnerability class for one assessment is not equivalent to a vulnerability class in another assessment.

Table 2: Projected changes in winter and summer rainfall (re-classed)

\begin{tabular}{|c|c|c|c|c|c|c|c|}
\hline \multicolumn{4}{|c|}{ Winter rainfall } & \multicolumn{4}{|c|}{ Summer rainfall } \\
\hline Class & Decrease (\%) & Class & Increase (\%) & Class & Decrease (\%) & Class & Increase (\%) \\
\hline 0 & - & 0 & -39.3 to 0 & 0 & - & 0 & -83.7 to 0 \\
\hline 1 & 39.7 to 0 & 1 & 0 to 4 & 1 & 53.8 to 0 & 1 & 0 to 5.5 \\
\hline 2 & 0 to -4.4 & 2 & 4 to 8 & 2 & 0 to -9.3 & 2 & 5.5 to 11 \\
\hline 3 & -4.4 to -8.7 & 3 & 8 to 12 & 3 & -9.3 to -18.6 & 3 & 11 to 16.5 \\
\hline 4 & -8.7 to -13.1 & 4 & 12 to 16 & 4 & -18.6 to -27.9 & 4 & 16.5 to 22 \\
\hline 5 & -13.1 to -17.5 & 5 & 16 to 20 & 5 & -27.9 to -37.2 & 5 & 22 to 27.5 \\
\hline 6 & -17.5 to -21.8 & 6 & 20 to 24 & 6 & -37.2 to -46.5 & 6 & 27.5 to 33 \\
\hline 7 & -21.8 to -26.2 & 7 & 24 to 28 & 7 & -46.5 to -55.8 & 7 & 33 to 38.5 \\
\hline 8 & -26.2 to -30.6 & 8 & 28 to 32 & 8 & -55.8 to -65.1 & 8 & 38.5 to 44 \\
\hline 9 & -30.6 to -34.9 & 9 & 32 to 36 & 9 & -65.1 to -74.4 & 9 & 44 to 49.5 \\
\hline 10 & -34.9 to -39.3 & 10 & 36 to 39.7 & 10 & -74.4 to -83.7 & 10 & 49.5 to 53.8 \\
\hline
\end{tabular}


Table 3: Projected changes to heavy rainfall, run-off and temperature (re-classed)

\begin{tabular}{|c|c|c|c|c|c|}
\hline \multicolumn{2}{|c|}{ Heavy rainfall } & \multicolumn{2}{|c|}{ Run-off } & \multicolumn{2}{|c|}{ Temperature } \\
\hline Class & Increase (\%) & Class & Increase (\%) & Class & Increase (\%) \\
\hline 0 & -8.1 to 0 & 0 & - & 0 & - \\
\hline 1 & 0 to 2 & 1 & -59.5 to 0 & 1 & 0 to 0.46 \\
\hline 2 & 2 to 4 & 2 & 0 to 4.1 & 2 & 0.46 to 0.91 \\
\hline 3 & 4 to 6 & 3 & 4.1 to 8.2 & 3 & 0.91 to 1.37 \\
\hline 4 & 6 to 8 & 4 & 8.2 to 12.3 & 4 & 1.37 to 1.82 \\
\hline 5 & 8 to 10 & 5 & 12.3 to 16.5 & 5 & 1.82 to 2.27 \\
\hline 6 & 10 to 12 & 6 & 16.5 to 20.6 & 6 & 2.27 to 2.73 \\
\hline 7 & 12 to 13.1 & 7 & 20.6 to 24.7 & 7 & 2.73 to 3.19 \\
\hline- & - & 8 & 24.7 to 28.8 & 8 & 3.19 to 3.64 \\
\hline- & - & 9 & 28.8 to 32.9 & 9 & 3.64 to 4.10 \\
\hline- & - & 10 & 32.9 to 37.0 & 10 & 4.10 to 4.55 \\
\hline
\end{tabular}

\subsubsection{Water quality: Dilution}

Surface water quality data was taken from the European Environment Agency (EEA) Water Framework Directive (WFD) Surface Water Viewer (in January 2012) (EEA, 2012), and the percentage of water bodies (within a River Basin District - RBD) that fell into the Poor and Bad classes was calculated. This data was then linearly re-classed onto a scale of 1 to 10 ( $1=0$ $10,2=10-20$, etc. $)$.

Two aspects relating to ecosystem services were explored using this data, dilution and filtration, on the basis that both these services can contribute to reducing water pollution and thus improve its quality. Dilution and filtration services are not unconnected as clearly filtration can impact on dilution and vice versa. However, with respect to potential RDP interventions, there are likely to some operations (e.g. buffer strips) which may specifically impact upon 
filtration capacity and others which may impact on both filtration and dilution (e.g. reduced pollutant loads). Thus the two services are differentiated here to aid this analysis.

With respect to dilution, decreases in rainfall could result in less water available to dilute pollutants entering water bodies. Consequently in areas where there are currently water pollution issues, projected decreases in rainfall may result in less dilution and thus an increase in the concentration of pollutants and lower water quality. To reflect this issue, water quality data was combined with projections of decreases in winter and summer rainfall. This was done by re-classing the winter and summer rainfall projections onto a scale of 1 to 10 as shown in Table 2.

Water quality dilution vulnerability was calculated using Equation 1, resulting in vulnerability map shown in Figure 1a.

Water quality: Dilution vulnerability $=(($ DWRC + DSRC $) / 2) \times$ WQC

Where:

DWRC $=$ Decrease in Winter Rainfall Class

DSRC $=$ Decrease in Summer Rainfall Class

WQC $=$ Water Quality Class

(Equation 1)

\subsubsection{Water quality: Filtration}

With respect to filtration, the issue filtering pollutants in surface run-off (rather than filtration in groundwater) was focused on. A similar approach to dilution was adopted, in that areas where there are currently water pollution issues, projected increases in run-off could require greater capacity for filtration in order to ensure pollutant loads into surface water do not increase due to increased run-off of pollutants. To reflect this issue, water quality data was combined with projections of increases in run-off. This was done by re-classing the run-off projections onto a scale of 1 to 10 as shown in Table 3. 
Water quality filtration vulnerability risk was calculated using Equation 2, resulting in the vulnerability map shown in Figure $1 \mathrm{~b}$.

Water quality: Filtration vulnerability risk $=$ IRC $\times$ WQC

Where:

IRC $=$ Increase in Run-off Class

WQC $=$ Water Quality Class

(Equation 2)

\subsubsection{Water regulation: Flooding}

Flooding is a well documented concern with respect to climate change (Booij, 2005; Christensen and Christensen, 2003; Prudhomme et al., 2013). As such there already has been a lot of work undertaken to spatially analyse where there may be areas of concern. The work undertaken for the PESETA (Projection of Economic impacts of climate change in Sectors of the European Union based on boTtom-up Analysis) project (Ciscar et al., 2009) was used as the basis for the flooding vulnerability map. The PESETA project used the IPCC SRES scenario A2 and NUTS2 level to calculate a projected change in damage of river floods with a 100-year return period between 2071-2100 and 1961-1990. This data was linearly re-classed onto a scale of 1 to 10 as shown in Table 4 . 
Table 4: Projected change in damage of river floods with a 100-year return period between 2071-2100 and 1961-1990 (re-classed)

\begin{tabular}{|c|c|}
\hline Class & Projected change (\%) \\
\hline 0 & $-44.9-0$ \\
\hline 1 & $0-9$ \\
\hline 2 & $9-18$ \\
\hline 3 & $18-27$ \\
\hline 4 & $27-36$ \\
\hline 5 & $36-45$ \\
\hline 6 & $45-54$ \\
\hline 7 & $54-63$ \\
\hline 8 & $63-72$ \\
\hline 9 & $72-81$ \\
\hline 10 & $81-92.9$ \\
\hline & \\
\hline
\end{tabular}

As there data already incorporated climate change projection, the data in Table 4 were plotted to produce the vulnerability map shown in Figure 1c.

\subsubsection{Water provision}

The assessment of vulnerability with respect to water provision focused on those areas that are already water stressed combined with projections of decreases in winter and summer rainfall. For water stress, data from Vörösmarty et al. (2010) have been combined into a single water stress index. Vörösmarty et al. (2010) present 23 drivers in relation to water stress, however for the purposes of this study, three indicators with the most relevance to water provision (for human use) were selected:

- Consumptive water loss (0.43)

- Human water stress $(0.33)$

- Agricultural water stress (0.24) 
These have been combined into a single index using the weightings shown in brackets above (following the proportions used by Vörösmarty et al., 2010). Vörösmarty et al. (2010) used a scale of 0 to 1 for each indicator, so the resulting single index is also 0 to 1 . This index was then linearly re-classed to 0 to 10 (where 0 to $0.1=1,0.1$ to $0.2=2$, etc.), thus facilitating combination with the climate data. This water stress index has then been combined with projections on decreases in winter and summer rainfall and the water provision vulnerability risk was calculated using Equation 3, resulting in the vulnerability map shown in Figure 1d.

$$
\text { Water provision vulnerability }=\text { WSC } \times((D W R C+D S R C) / 2)
$$

Where:

WSC $=$ Water Stress Class

DWRC $=$ Decrease in Winter Rainfall Class

DSRC $=$ Decrease in Summer Rainfall Class

(Equation 3)

\subsubsection{Soils: Erosion}

Soil erosion is a key issue for agricultural production as the loss of soil can result in decreases in agricultural productive capability. Increases in rainfall can increase overland flow and thus the risk of soil erosion, and increased days of heavy rainfall can also contribute to increases in soil erosion (Kirkby et al., 2003). Projected increases in winter, summer and heavy rainfall were re-classed as shown in Table 2.

The data shown in Tables 2 and 3 were combined using Equation 4, resulting in a Rain_inc with 35 classes.

$$
\text { Rain_inc }=((\text { IWRC }+ \text { ISRC }) / 2) \times \text { IHRC }
$$

Where:

$$
\begin{aligned}
& \text { IWRC }=\text { Increase in Winter Rainfall Class } \\
& \text { ISRC }=\text { Increase in Summer Rainfall Class } \\
& \text { IHRC = Increase in Heavy Rainfall Class }
\end{aligned}
$$


To assess the vulnerability of an increase in soil erosion due to climate change, data on soil erosion risk were required. The soil risk assessment undertaken for the PESERA project (Kirkby et al., 2003) was drawn upon for this work. This data was re-classed into 8 classes using the same classification used in the PESERA project as shown in Table 5:

Table 5: PESERA soil erosion estimates ( $t / h a / y r)$ (re-classed)

\begin{tabular}{|c|c|}
\hline Class & t/ha/yr \\
\hline 1 & $0-0.5$ \\
\hline 2 & $0.5-1$ \\
\hline 3 & $1-2$ \\
\hline 4 & $2-5$ \\
\hline 5 & $5-10$ \\
\hline 6 & $10-20$ \\
\hline 7 & $20-50$ \\
\hline 8 & $50-426.61$ \\
\hline
\end{tabular}

Data from the PESERA project, on the risk to soil erosion by water, were then combined with the project increased rainfall data (Rain_inc). To provide a more equal weighting to the soil erosion risk, Rain_inc was linearly re-classed into 7 classes (i.e. $0-5=1,5-10=2$, etc) to give Rain_inc_rc. Note: zero Rain_inc is given a score of 1 so that when it multiplied with soil erosion below, any soil erosion risk will score 1 rather than 0 . The soil erosion vulnerability was then calculated by simply multiplying the soil erosion data by the increase in rainfall data as shown in Equation 5, resulting in the vulnerability map shown in Figure 1e.

Soils: Erosion vulnerability $=$ PESERA $x$ Rain_inc_rc

Where:

PESERA $=$ PESERA Class 
(Equation 5)

\subsubsection{Soils: Organic matter}

Soil organic matter (SOM) is composed of dead and decaying plant and animal tissue of which $58 \%$ is carbon (C) (IPCC, 2006). In the context of climate change, SOM is not only important with respect to sequestration of atmospheric $\mathrm{C}$, but also from the perspective of general soil quality and the fertility of the soil. Organic matter binds soil particles, prevents compaction and run-off, permits movement of air and water, facilitates seed germination and plant root penetration, and absorbs and retains soil moisture (NSRI, 2001). Decreases in SOM are therefore not only undesirable from a carbon storage perspective but can also result in poorer soil structure, reduced water retentive capacity and decreased crop yield. Generally, an increase in temperature and decrease in precipitation correlates with increased rates of OM oxidation to $\mathrm{CO}_{2}$, and smaller quantities of OM within the soil (Jones et al., 2004). Lower levels of SOM are typically observed in southern Europe compared to an equivalent land use and soil type in more northerly climates. Projected changes in climate of pertinence to SOM include decreased winter and summer rainfall and an increase in temperature, all of which have potential to result in a decrease in SOM (Jones et al., 2004).

Projected decreases in winter and summer rainfall were re-classed onto a scale of 1 to 10 as shown in Table 2, and changes in temperature were re-classed as shown in Table 3.

The existing SOM content of soils has been drawn from the JRC map of soil organic carbon content (Jones et al., 2005 and JRC 2012) and has been re-classed into 8 classes (0 to 7) using the same classification as the JRC (2012) as shown in Table 6. 
Table 6: Soil organic carbon content $(\%)$ in the surface horizon of soils in Europe (reclassed)

\begin{tabular}{|c|c|}
\hline Class & SOC (\%) \\
\hline 0 & $-3.4-0$ \\
\hline 1 & $0-0.99$ \\
\hline 2 & $0.99-2$ \\
\hline 3 & $2-6$ \\
\hline 4 & $6-12.5$ \\
\hline 5 & $12.5-20$ \\
\hline 6 & $20-35$ \\
\hline 7 & $35-63$ \\
\hline
\end{tabular}

Soil organic matter vulnerability is calculated using Equation 6, resulting in the vulnerability map shown in Figure 1f.

Soils: Organic matter vulnerability $=(((D W R C+D S R C) / 2)+$ ITC $) \times$ SOCC

Where:

DWRC $=$ Decrease in Winter Rainfall Class

DSRC $=$ Decrease in Summer Rainfall Class

ITC $=$ Increase in Temperature Class

SOCC $=$ Soil Organic Carbon Class

(Equation 6)

\subsubsection{Biodiversity: Forest fires}

Increased incidence of forest fires is not a new phenomenon during periods of hot and dry weather. Therefore projected increases in temperature and decreases in summer rainfall could result in an increased risk of forest fires, which not only impacts on biodiversity, but also 
impacts upon the provision timber, recreational and cultural ecosystem services (Lindner et al., 2010).

The assessment of vulnerability of forests to increased incidence of forest fires is relatively simple. Projected decreases in summer rainfall and increases annual temperature (re-classed as shown in Tables 2 and 3) are combined with CORINE land cover data (EEA, 2006) on forested areas using Equation 7, resulting in the vulnerability map shown in Figure 1g.

Biodiversity: Forest fires vulnerability $=($ ITC $\times$ DSRC $) \times$ FC

Where:

DSRC $=$ Decrease in Summer Rainfall Class

ITC $=$ Increase in Temperature Class

$\mathrm{FC}=$ Forest Class $(1$ or 0 if forest present or not)

(Equation 7)

\subsubsection{Biodiversity: Migration}

This is a complex area which is difficult to assess at a European scale. It is based on the assumption that increases in temperature will create pressure for species to migrate to cooler areas, be that northwards or upward in altitude (Bellard et al., 2012; Dawson et al., 2011; Jackson et al., 2009; Pearson, 2006). Therefore the diversity of elevation and level of habitat fragmentation will impact upon species with respect to their vulnerability to temperature increase (i.e. ability to migrate).

Elevation diversity within a NUTS3 region has been derived using the standard deviation of elevation within the NUTS3 region, which then linearly re-classed into 10 classes of elevation diversity as shown in Table 7. This was derived from the EEA elevation map of Europe (EEA, 2004) which is made using the global digital elevation model (DEM) derived from GTOPO30 (note: the units used are ArcGIS metrics and are not altitude in metres). 
Table 7: Elevation diversity in Europe (re-classed)

\begin{tabular}{|c|c|}
\hline Class & Standard deviation in NUTS3 area \\
\hline 1 & 66 to 73.3 \\
\hline 2 & 58.6 to 66 \\
\hline 3 & 51.3 to 58.6 \\
\hline 4 & 44 to 51.3 \\
\hline 5 & 36.7 to 44 \\
\hline 6 & 29.3 to 36.7 \\
\hline 7 & 22 to 29.3 \\
\hline 8 & 14.7 to 22 \\
\hline 9 & 7.3 to 14.7 \\
\hline 10 & 0 to 7.3 \\
\hline
\end{tabular}

Habitat/landscape fragmentation data were taken from a study on landscape fragmentation in Europe (EEA, 2011) and were re-classed onto a scale of 0 to 10 (using the same classification used in the EEA study) as shown in Table 8. 
Table 8: Landscape fragmentation in Europe (re-classed)

\begin{tabular}{|c|c|}
\hline Class & Number of meshes per $1000 \mathrm{~km} 2$ \\
\hline 0 & $-2-0$ \\
\hline 1 & $0-0.1$ \\
\hline 2 & $0.1-0.25$ \\
\hline 3 & $0.25-0.5$ \\
\hline 4 & $0.5-1$ \\
\hline 5 & $1-5$ \\
\hline 6 & $5-10$ \\
\hline 7 & $10-25$ \\
\hline 8 & $25-50$ \\
\hline 9 & $50-100$ \\
\hline 10 & $100-100078008$ \\
\hline
\end{tabular}

Habitat/landscape fragmentation data and projected increases in temperature were then combined as shown in Equation 8, resulting in the vulnerability map shown in Figure 1h.

Biodiversity: Migration vulnerability $=((E D C+H F C) / 2) \times$ ITC

Where:

$\mathrm{EDC}=$ Elevation Diversity Class
HFC $=$ Habitat Fragmentation Class
ITC $=$ Increase in Temperature Class

(Equation 8)

\subsubsection{Biodiversity: Pollination}

Pollination is a key ecosystem service, for example insect pollination in the EU has an estimated economic value of $€ 15$ billion per annum (Gallai et al., 2009). Climate change poses a number of issues for pollinators, especially increases in temperature. Changes in 
temperature may affect the timing of flower plants and thus pollinators become desynchronised with the plants on which they depend; there can increases in pest and disease pressure; temperature may affect foraging patterns; and temperature may affect the migration/location of pollinators (de Groot et al., 2010; Potts et al., 2010; UNEP, 2010).

To assess the potential risk posed by climate change to pollination, projected increases in temperature (see Table 3) were combined with data on the proportion of crops requiring pollination (sugar beet; oilseeds; sunflower; oil flax; soya bean; cotton seed; fruit trees; soft fruit; and vineyards) (based on Eurostat statistics for area of crops grown 2002 to 2011) (Eurostat, 2012). This is designed to reflect a potential decrease in the population of pollinators (due to temperature change) in the areas where they are most needed to pollinate crops. The proportion of crops requiring pollination was linearly re-classed onto a scale of 1 to 5 as shown in Table 9.

Table 9: Proportion of crops requiring pollination (re-classed)

\begin{tabular}{|c|c|}
\hline Class & Proportion of cropped area (\%) \\
\hline 1 & $0-18.4$ \\
\hline 2 & $18.4-36.9$ \\
\hline 3 & $36.9-55.3$ \\
\hline 4 & $55.3-73.8$ \\
\hline 5 & $73.8-92.2$ \\
\hline
\end{tabular}

The pollination vulnerability assessment is calculated using Equation 9, resulting in the vulnerability map shown in Figure 1i.

Biodiversity: Pollination vulnerability $=$ CRPC $x$ ITC

Where:

CRPC $=$ Crops Requiring Pollination Class

ITC $=$ Increase in Temperature Class 
(Equation 9)

\subsection{Results}

\subsubsection{Vulnerability assessments}

The outputs from the vulnerability assessments described above consist of spatial data in a raster format. This spatial data consists of a number of classes, which varies with each vulnerability assessment, ranging from low to high vulnerability. The results of the vulnerability are presented in Figure 1 in the form of maps of Europe showing the distribution of the different vulnerability classes.

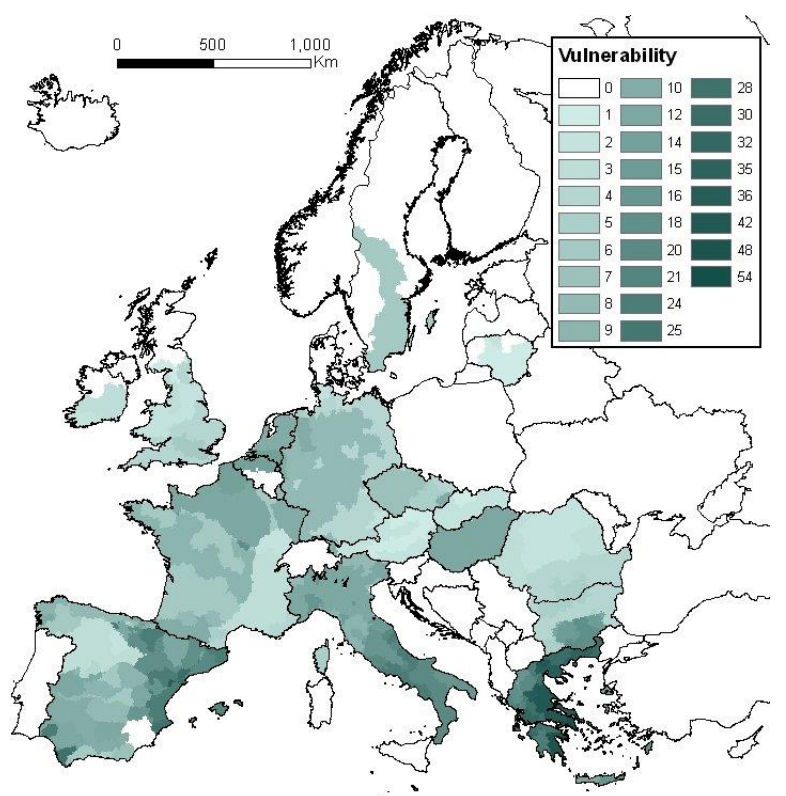

(a) Water quality: Dilution

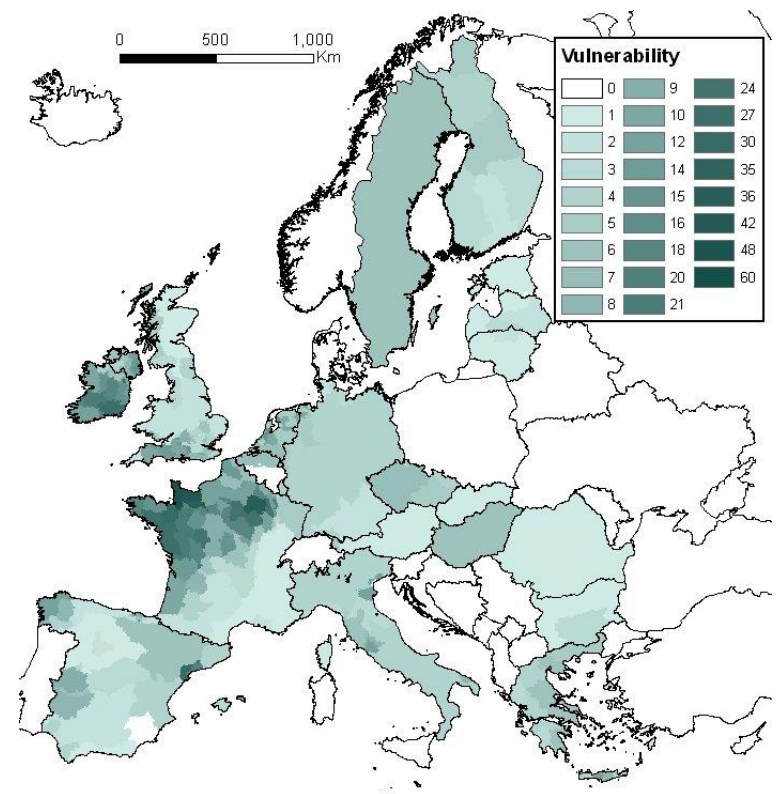

(b) Water quality: Filtration 


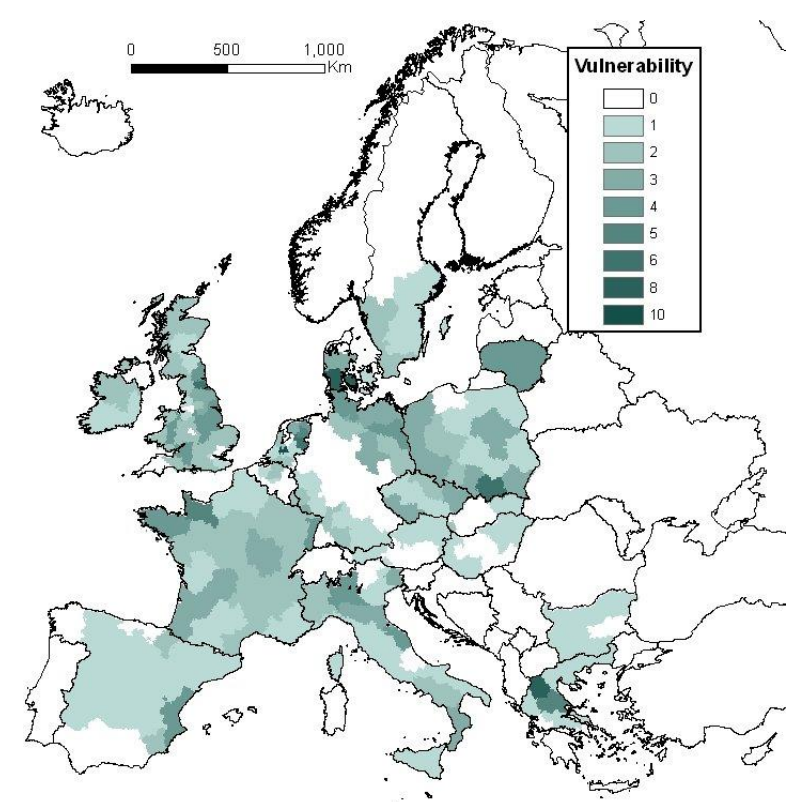

(c) Water regulation: Flooding

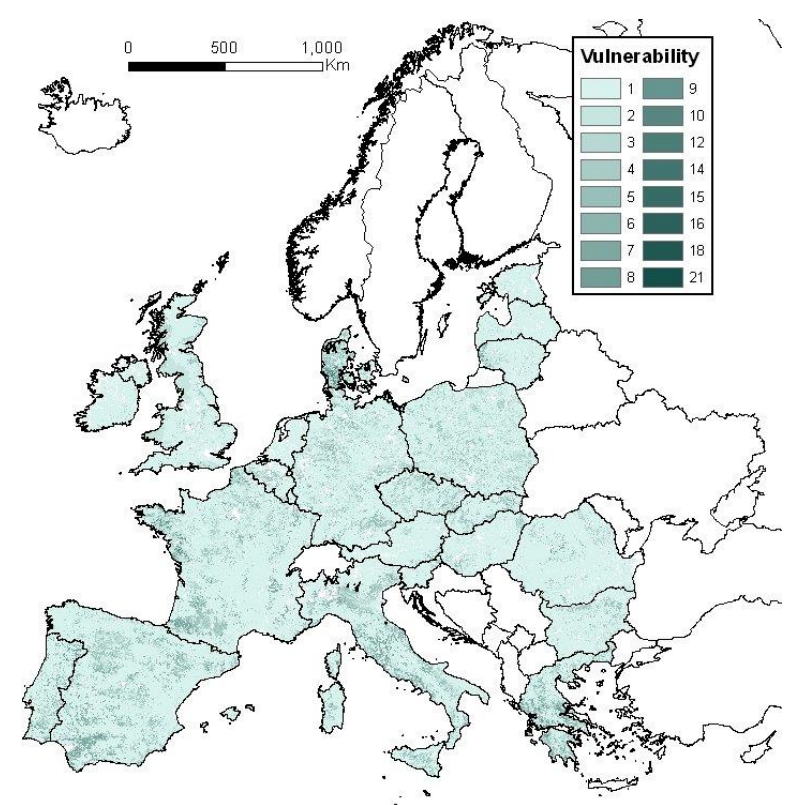

(e) Soils: Erosion

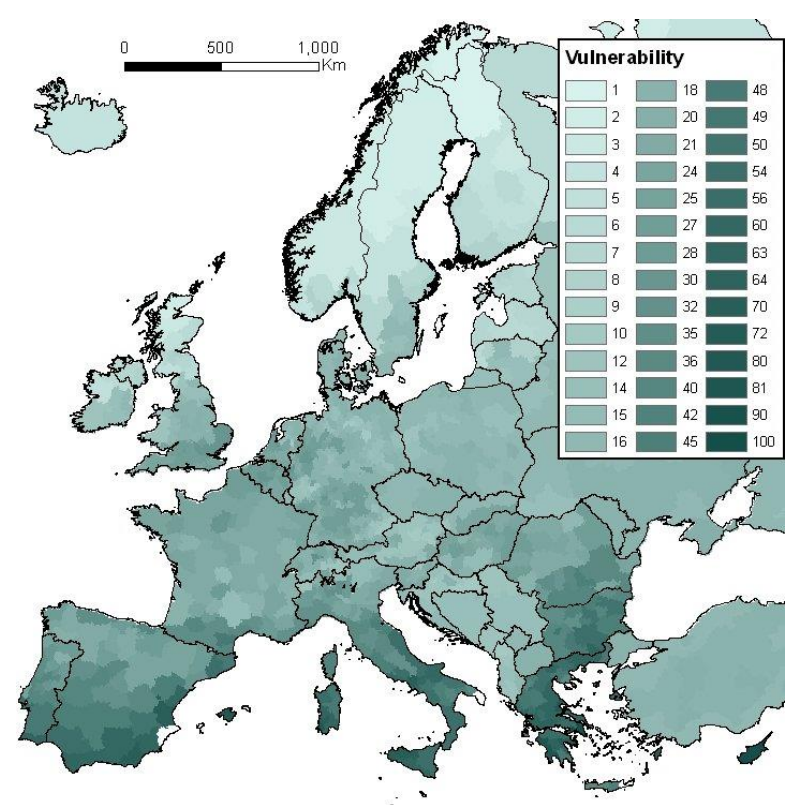

(d) Water provision

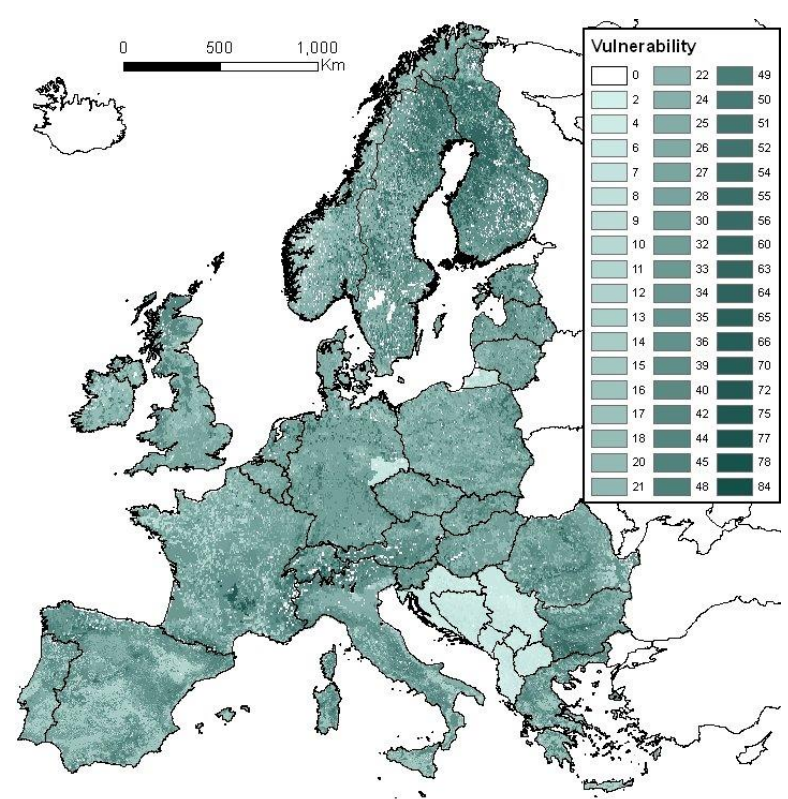

(f) Soils: Organic matter 


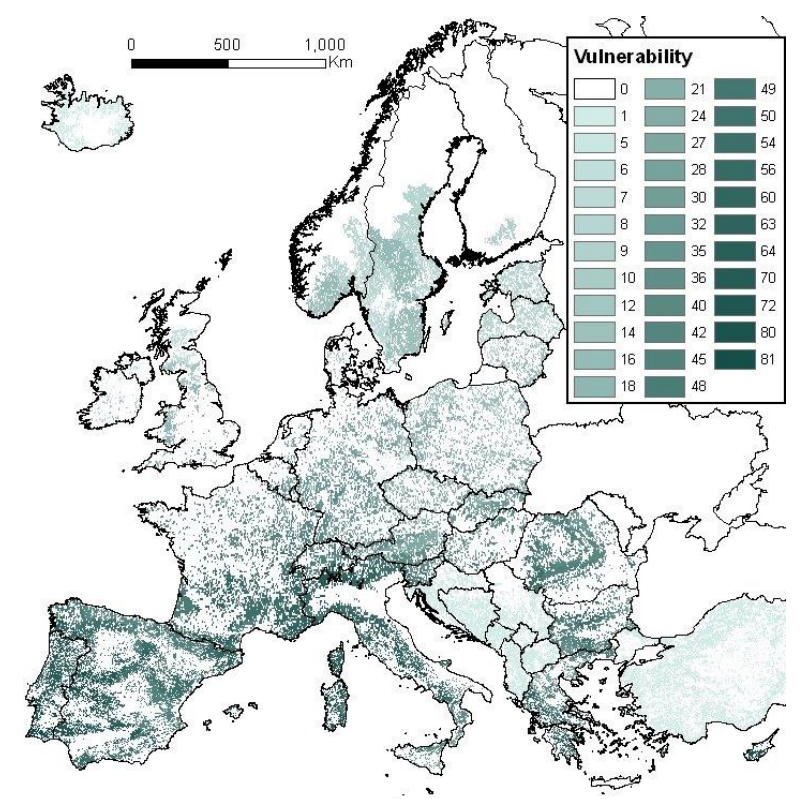

(g) Biodiversity: Forest fires

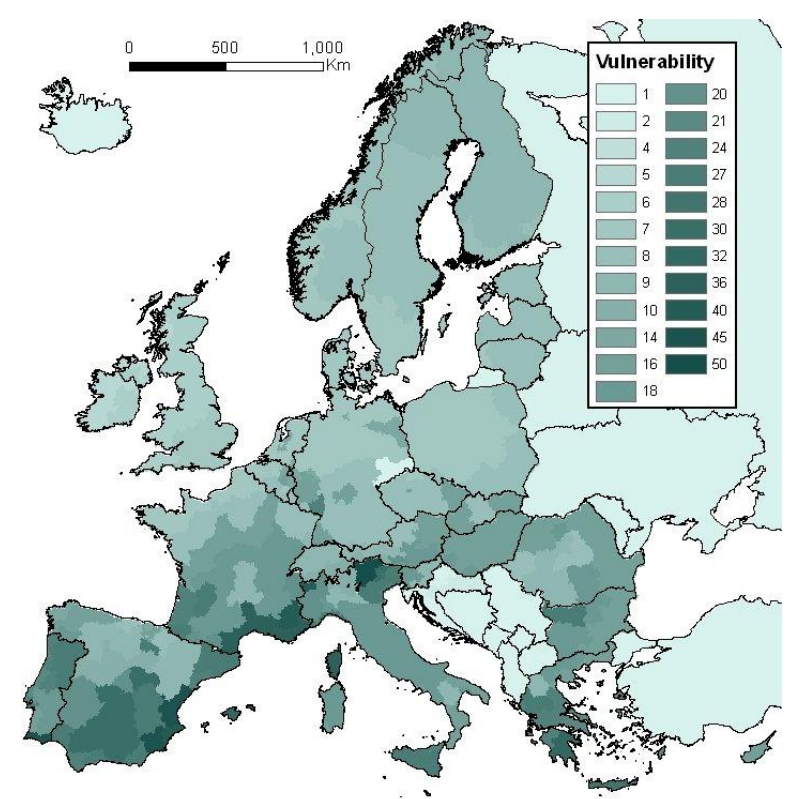

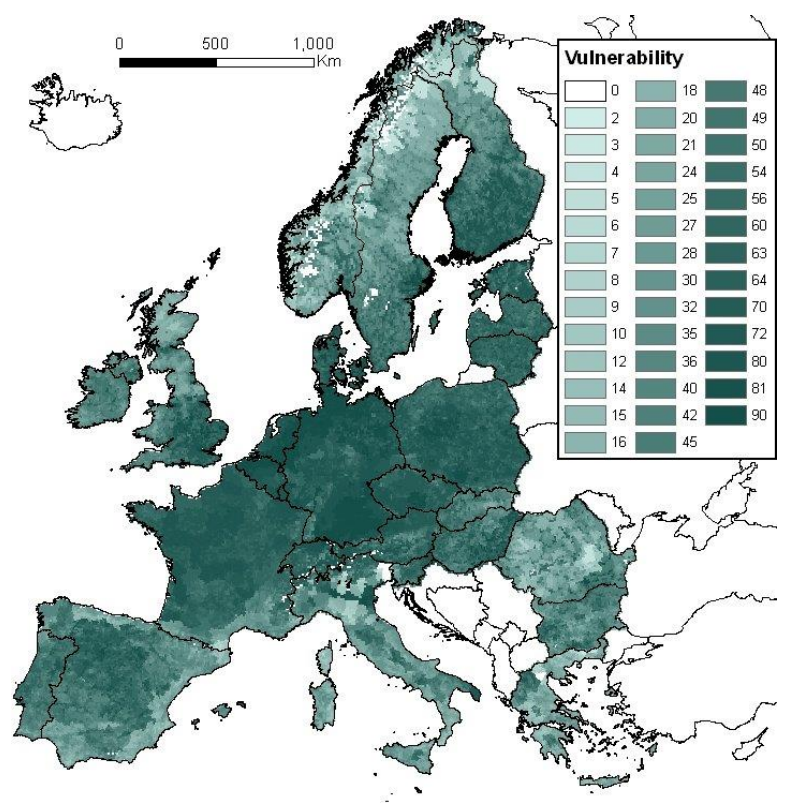

(h) Biodiversity: Migration

(i) Biodiversity: Pollination

Figure 1: Vulnerability assessment results maps for the EU-27

Table 10 shows the range of theoretical vulnerability classes that could exist for each ecosystem service and the range that exists in the EU-27. In many instances the theoretical range is also closely if not fully represented in the EU-27. The two soils services are the main exception, with the higher vulnerability classes not found in the EU-27. 
Table 10: Range of vulnerability classes

\begin{tabular}{|l|l|l|}
\hline Ecosystem service & Theoretical range & EU-27 range \\
\hline Water quality: Dilution & 0 to 100 & 0 to 54 \\
\hline Water quality: Filtration & 0 to 70 & 0 to 60 \\
\hline Water regulation: Flooding & 0 to 10 & 0 to 10 \\
\hline Water provision & 0 to 100 & 0 to 100 \\
\hline Soils: Erosion & 0 to 56 & 0 to 21 \\
\hline Soils: Organic matter & 0 to 140 & 0 to 84 \\
\hline Biodiversity: Forest fires & 0 to 100 & 0 to 81 \\
\hline Biodiversity: Migration & 0 to 100 & 0 to 90 \\
\hline Biodiversity: Pollination & 0 to 50 & 0 to 50 \\
\hline
\end{tabular}

\subsubsection{Hotspots}

With respect to hotspots, all the vulnerability maps presented above clearly demonstrate regional variation on a European scale. In some instances this variation is only at a NUTS2 or NUTS3 level (e.g. pollination or flooding), but in other instances the variation is at a finer resolution (e.g. soil erosion, SOM or forest fires). This largely stems from the resolution of the underlying data used. However, even at a NUTS2 or NUTS3 level, it is possible to determine some areas where there are potential adaptation hotspots For example:

- Water quality dilution issues in eastern Spain and Greece.

- Water filtration capacity issues in north-west France and Ireland.

- Flooding issues in north-east England.

- Water provision issues in southern European countries.

- Soil erosion issues in Denmark.

- Soil organic matter issues in the Auvergne region in southern France.

- Forest fire issues throughout southern Europe, particularly in south-west Spain and Portugal, Sardinia and Corsica, and Cyprus.

- Biodiversity Migration issues throughout the densely populated areas of northern Europe and patches in southern Europe. 
- Pollination issues in southern Spain and France and north-east Italy.

It is also possible to perform basic spatial analysis to determine the proportion of a region that falls into different vulnerability classes. For example, we can divide the European range (in Table 10) for each vulnerability assessment into thirds, to represent low, moderate and high vulnerability classes. It is then possible to determine the proportion of the land area of a region (as a percentage of the total) that falls into the moderate and high classes. For example, Table 11 presents this data as a hotspot analysis for nine rural NUTS3 regions, 3 in north-eastern England in the UK, 3 in north-west France and 3 is south-east Spain.

Table 11: Example of adaptation hotspot analysis for regions in France, Spain and the UK

\begin{tabular}{|c|c|c|c|c|c|c|c|c|c|c|}
\hline \multirow[b]{2}{*}{ NUTS3 region } & \multirow[b]{2}{*}{$\begin{array}{l}\text { Land } \\
\text { area } \\
\left(\mathrm{km}^{2}\right)\end{array}$} & \multicolumn{9}{|c|}{ Percent $(\%)$ of land area } \\
\hline & & 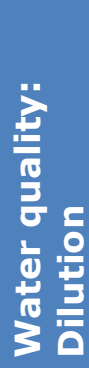 & 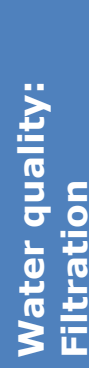 & 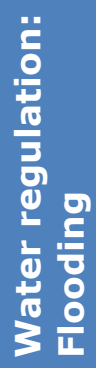 & $\begin{array}{l}\frac{5}{0} \\
\frac{0}{5} \\
\frac{0}{2} \\
\frac{2}{2} \\
\frac{1}{d} \\
\frac{3}{3}\end{array}$ & $\begin{array}{l}\frac{5}{0} \\
\frac{0}{0} \\
\frac{5}{4} \\
\frac{6}{2} \\
\frac{0}{8}\end{array}$ & 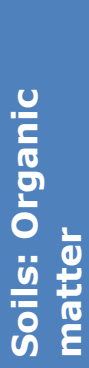 & 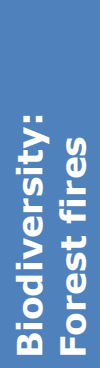 & 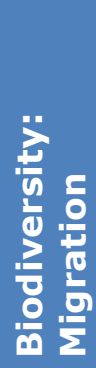 & 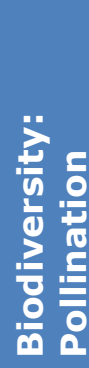 \\
\hline \multicolumn{11}{|c|}{ North-east England, UK } \\
\hline Durham CC & 2203 & 0 & 0 & 100 & 0 & 0 & 32 & 0 & 60 & 0 \\
\hline Northumberland & 4966 & 0 & 0 & 100 & 0 & 0 & 35 & 0 & 44 & 0 \\
\hline North Yorkshire CC & 7939 & 0 & 0 & 0 & 0 & 0 & 27 & 0 & 29 & 0 \\
\hline \multicolumn{11}{|c|}{ Basse-Normandie, France } \\
\hline Calvados & 5540 & 0 & 94 & 100 & 0 & 0 & 3 & 100 & 100 & 0 \\
\hline Manche & 5939 & 0 & 93 & 100 & 0 & 0 & 2 & 100 & 100 & 0 \\
\hline Orne & 6080 & 0 & 48 & 100 & 0 & 0 & 39 & 100 & 100 & 0 \\
\hline \multicolumn{11}{|l|}{ Cataluña, Spain } \\
\hline Girona & 5923 & 100 & 0 & 0 & 100 & 1 & 69 & 100 & 0 & 100 \\
\hline Lleida & 12203 & 0 & 0 & 0 & 0 & 0 & 41 & 100 & 58 & 100 \\
\hline Tarragona & 6337 & 100 & 54 & 0 & 0 & 0 & 22 & 100 & 2 & 100 \\
\hline
\end{tabular}


Table 11 shows both the variation between the three countries, but also variations between the NUTS3 regions within those countries with respect the proportion of the land that is moderately and highly vulnerable. For example, Durham and Northumberland in the UK have a high proportion of land that is vulnerable for flooding; Orne in France has a high area of land where SOM is vulnerable; and Lleida in Spain has a high proportion of land that is vulnerable for biodiversity migration.

Given these hotspots, there may be scope within RDPs to develop operations to address these issues - some examples in relation to the rural development priorities (EC, 2011) of water, soil and biodiversity are discussed below.

\subsubsection{Example RDP operations}

With respect to water quality, there is not normally scope to increase dilution (i.e. quantity of water) to improve quality. Therefore, reducing pollutant loads may help reduce concentrations of pollutants in regions where there is less dilution capacity (Figure 1a) due to climate change. For example, in rural areas this may include reducing losses of nutrients and pesticides from agriculture. This could be coupled with increasing filtration capacity in areas where increased run-off may occur due to climate change (Figure 1b). For example, increasing buffer strips around arable fields or designing and implementing more effective buffer strips may increase the filtration capacity within a region and thus help improve water quality.

In relation to the regulation of water flows, there can be efforts to attenuate flood peaks/flows in areas where there are flooding issues (Figure 1c). For example, increasing the water holding capacity of land, e.g. the restoration of upland moorland and peat bogs may help buffer heavy rainfall events and thus help attenuate flood peaks. At the other extreme, where there are deficiencies in water provision (Figure 1d), action tends to focus on reducing demand, increasing water efficiency or better capture and storage of water resources. For example, in areas currently water stressed and where rainfall is projected to decrease, more efficient irrigation of crops (technological and biological), or capturing and storing water when it is plentiful (e.g. in reservoirs) may help increase the capacity of an area to cope with water provision issues. 
In the context of soil protection, the issue of soil erosion is not a new phenomenon. Thus it is a case of implementing soil conservation techniques in areas which are prone to erosion. Those those areas identified as at an increased risk due to climate change (Figure 1e) can target rural development funds towards soil erosion control techniques and technologies. The issue of soil organic matter is a more complex area and can be cross-cutting as it also impacts on soil erosion, water provision/use by crops, carbon sequestration and agricultural production. Areas identified as being vulnerable (Figure 1f) are most likely to benefit from RDP operations to conserve SOM or increase it. This could be via inclusion of a 1-2 year grass/clover ley following an undersown spring crop, sensitive management of high erosion risk crops (e.g. maize) or using reduced depth non-inversion tillage (Dawson and Smith, 2007). In southern Europe, zero tillage may be an effective technique but with minimal risk of increased $\mathrm{N}_{2} \mathrm{O}$ emission (Helgason et al., 2005; Marland et al., 2001). Avoidance of soil compaction by livestock in northern Europe (e.g. by removal of livestock from vulnerable grazing land during the winter) provides the opportunity to enhance grass growth and return of organic matter to the soil on grasslands (Louwagie et al., 2009; Moorby et al., 2007).

Regarding biodiversity, although forest fires can be part of natural ecosystem processes (Brūmelis et al., 2011), in the context of the densely populated areas of Europe, and the ecosystem services forests provide, they are undesirable (Lindner et al., 2010). There are two aspects to focus on, fire prevention and fire fighting. In regions where there may be an increased risk of forest fires (Figure 1g), RDPs could be used to implement operations to reduce the risk of fire, for example removal of forest trash as potential fuel source or creation of fire breaks (PNW, 2010). Additionally, in areas of increased risk, improved fire fighting infrastructure may also help increase the capacity of the region to deal with forest fires.

Biodiversity migration (Figure $1 \mathrm{~h}$ ) is a challenge in the densely populated areas of Europe. However, there may be scope, especially in rural areas, to address habitat fragmentation issues. For example, the creation of wildlife corridors to connect patches of habitat may help reduce fragmentation and/or increase the capacity for biodiversity to migrate when faced with changes in climate. The issue of pollination vulnerability (Figure 1i) is also partly connected to migration, but with a focus on the population of pollinating species. Efforts to tackle the 
migration issue may help pollinators, but more specific action might include the creation of habitat to support greater numbers of pollinators in and around crops that require pollination.

Different operations will have different degrees of impact with respect to increasing the capacity of a regions ecosystem services to adapt to climate change. Quantifying the degree of impact is a challenging task, especially when (as discussed above) there is no unit of adaptive capacity. However, at a basic level it is possible to use expert judgement to provide an indication of relative degree of impact that might be expected from two or more operations. If a nominal index of this relative impact is used, it can then be combined with the vulnerability scores (classes) shown above. For example, if the relative impact score of an operation is multiplied by the vulnerability class in the location it is applied, these scores across a whole region (with multiple vulnerability classes) would provide an overall relative measure of the potential impact of an operation with a region. It does not quantify the impact on adaptive capacity, but it provides a numerical means of assessing relative potential impact when considering multiple operations, as is the case when developing rural development programmes. As such it facilitates the focusing of relevant operations in the areas that most need them.

\subsection{Discussion and conclusions}

\subsection{Fitness for purpose}

The vulnerability assessments presented above are in many respects relatively simple. They are based on data that are readily available for the EU-27 and in format to allow spatial analysis. There will always scope to use 'better' data, e.g. data of a higher resolution, more recent data, or more complex data/greater number of parameters. However, the key issue to determine is are they fit for purpose and suitable for the application for which they were developed.

The work presented was undertaken in the context of developing European Rural Development Programmes (RDPs) for the 2014-2020 period to optimally address climate change objectives (reducing GHG emissions, increasing carbon sequestration and increasing capacity to adapt). 
The vulnerability assessments above can be used to support this process in two ways. Firstly, by aiding the identification of hotspots with respect to areas where they could be adaptation issues. Secondly, to help assess the potential impact RDP operations might have with respect to increasing the adaptive capacity of ecosystem services. As shown in the results, it is possible to use the vulnerability assessments for this task. However, there are undoubtedly a number of limitations and areas for improvement that need to be taken into consideration.

\subsection{Limitations and areas for improvement}

The vulnerability assessments presented herein provide a simple and pragmatic approach to tackling the issue of adaptation to climate change with respect to ecosystem services. However, they are a prototype and very much a 'first draft' and consequently there are a number of areas where they could be improved (without deviating from a simple approach utilising readily available data).

For example, with respect to water quality, data that underpins both the dilution and filtration vulnerability assessments was based on data that was available in early 2012 . This was a snap shot of what had been reported under the Water Framework Directive (WFD) up to that time. Since then additional data has been added (e.g. some data were missing in 2012 , such as that for Poland and Portugal) and other data have been updated. Consequently there is scope for this assessment to become out of date. It would be possible to revise the data set, however the WFD data are not readily available in a format suitable for GIS analysis - thus it is not conducive to regular updating. Additionally, the assessment of dilution was based on the WFD water quality data combined with projected percentage decreases in winter and summer rainfall (Table 2). This percentage data does not take account of existing levels of rainfall and thus volume of water available for the service of dilution. The impact on dilution in areas which are projected to have a large percentage decrease in rainfall but which have low rainfall to start with, may be less of an impact on dilution (in terms of volume of water) that areas which have a lower percentage decrease in projected rainfall but which have higher current rainfall. Consequently, in the vulnerability assessment shown in Figure 1a, some of the areas, for example Greece, which have been highlighted has having high vulnerability, may actually be 
less vulnerable due to lower existing rainfall. To overcome this, the projected percentage decrease in rainfall could be combined with current winter and summer rainfall, to determine an actual reduction in rainfall and thus volume.

The water provision vulnerability assessment utilised water stress indicators developed by Vörösmarty et al. (2010). Just three of the human water security (HWS) indicators provided by Vörösmarty et al. (2010) were selected. These were the key indicators, but there is scope to base the water stress indicator using all six of the HWS indicators (dam density, river fragmentation, consumptive water loss, human water stress, agricultural water stress, and flow disruption). Additionally, Vörösmarty et al. (2010) also provide an alternative weighting of the 6 indicators to provide an indicator of water stress on river biodiversity (BD). Thus there is scope to provide an alternative perspective on water stress and potentially water provision, i.e. from the perspective of water provision for biodiversity - thus providing an overlap with the water and biodiversity vulnerability assessments.

The biodiversity migration vulnerability assessment is one of the more complex assessments that have been undertaken. It presents an assessment for biodiversity for the whole area of Europe. However, in relation to the issue of the capacity of biodiversity to migrate, perhaps a more significant issue relates to areas where we protect and conserve our most valued and endangered species - such as the Natura 2000 network of designated sites. The problem with designated areas is that in the event of climate change we cannot extend a nature reserve northwards due to fragmentation and/or human infrastructure. Many of the Natura 2000 sites, and the species they contain, are surrounded by vulnerable areas. Consequently there may be scope to make an assessment of the degree of fragmentation to the north of Natura 2000 areas and/or the degree of elevation diversity within the areas, to make an assessment specifically for Natura 2000 areas. Additionally in relation to this issue, the assessment of fragmentation and elevation diversity is quite crude in resolution, especially with respect to the latter, which is elevation diversity within NUTS3 areas (i.e. there are single values for whole NUTS3 regions). The ability of biodiversity to migrate could depend on localised issues and features. For example, a NUTS3 region may have low elevation diversity, but there could be small area within that region which is rich in biodiversity and does have greater elevation 
diversity (i.e. it is hilly), and thus there could be scope for biodiversity to migrate by adjusting their altitude.

The pollination vulnerability assessment is based on projected temperature increase and the proportion of crops within a region that require pollination. There are two areas where potential improvements might be made. Firstly, as well as increased temperature, increases in rainfall, and especially heavy rainfall, may also have negative impacts on pollinating species because, for example, it may reduce the longevity of flowers reducing the availability of pollen and nectar production. There may be scope to incorporate projected changes in rainfall into the vulnerability assessment to address this issue. Secondly, the area of crops requiring pollination does not take into account the potential value and yield of the crop. There may be scope address this issue by multiplying crop value and yield by the area, thus highlighting where the most valuable and high yielding crops may be vulnerable.

Given the numerical vulnerability classes, there may be scope to combine some of the vulnerability assessments using tools within ArcGIS. In so doing this would enable the identification of regions where there are multiple vulnerability issues to address, and possibly compounding issues, where problems are exacerbated due to their incidence in one location. For example, regions where there may be water provision issues (Figure 1d) and risks of forest fires (Figure 1g), where clearly a lack of water may impact on a region's capacity to fight forest fires, in which case greater efforts (in terms of RDP measures and operations) should be targeted on fire prevention.

Data resolution is another area where improvements could be made. For example, the climate change projection data used was aggregated to European NUTS3 regions, which are relatively large areas and the boundaries are determined based on population, consequently population density impacts on geographical size. This means that in some sparsely populated areas, one set of climate change data covers a large geographical area, and when this is combined with similar low resolution data, e.g. water quality for river basin districts (RBDs), single vulnerability classes can cover large areas (e.g. see Filtration vulnerability in Sweden - Figure 1b). This could be improved by using either higher resolution (e.g. $1 \mathrm{~km}$ or $10 \mathrm{~km}$ grid) data for 
either the climate change or water quality data, or both. Similar issues exist for some of the other vulnerability assessments such as pollination.

Not unrelated to data resolution is the issue of uncertainty. This is particularly the case with climate change projections, where the issue of uncertainty has been a key issue and is a topic in its own right (Foley 2010; Moss et al., 2010; Pindyck 2013; Reto et al., 2010). There is also scope to adjust values in some of the indicators, e.g. the weightings used for the water provision index derived from Vörösmarty et al. (2010), and as described above there are different data sets for water quality. Thus there is scope to derive variations in the vulnerability assessments. It was beyond the scope of the project (given the number of variables) to undertake a full sensitivity analysis to identify the potential range that may arise in the results. However, it was acknowledged at the outset that the vulnerability assessments can only ever represent a snapshot and there is always scope to replicate the assessments with different data sets. For example, managing authorities in individual Member States may wish to use their own data (which may be higher resolution) or different climate projections bespoke to their region. In so doing this fits with the pragmatic approach of the framework developed, in making use of data that is readily available within the region of interest.

\subsection{Conclusions}

The work presented herein is currently (at the time of writing this article) being digested by the European Commission, so to do date there is little detailed feedback to report. However, the work was well received by the Commission and it is understood that they plan to develop it further in 2014 to support the development of RDPs in the EU-27. Despite the limitations outlined above, including the low data resolution and uncertainties, at a European level (and within some Member States) the vulnerability assessments do help shed light on some of the key adaptation issues for ecosystem services that may arise due to climate change and thus help inform the debate on potential responses in the context of rural development programmes and operations. However, like any government programme or policy, it is important to recognise that any decisions should not be based solely on assessments such as those presented herein. They should be used to in conjunction with other evidence including local 
knowledge and data to ensure that any interventions are well suited to the areas in which they are implemented. We also need to recognise that many interventions may need to be multifunctional, i.e. they may need to address multiple rural and environmental objectives. Climate change is only part of one of six EU priorities for rural development (EC, 2011).

The vulnerability assessments presented herein are fit for purpose at a basic level. They use readily available data to help inform complex decisions to support the EU rural development priority number 5: 'Promoting resource efficiency and supporting the shift towards a lowcarbon and climate-resilient economy in the agriculture, food and forestry sectors' (EC, 2011). As outlined above, there is considerable scope to improve the analyses, but given the pragmatic and relatively simplistic framework developed, there is scope for individual Member States to duplicate the process and address the areas for improvement as best meets their specific requirements and priorities. At the very least, especially in Member States that have to date lacked data and analyses of their regions, the vulnerability assessments provide an analysis of an issue not examined previously, but which is now of increasing importance as reflected in EU and national priorities.

Over the past decade there has been a growing acknowledgement that as well as tackling the causes of climate change (i.e. greenhouse gas emissions) that we need to adapt and respond to the changes in the climate that do arise, and this is now reflected in the policies and strategies at European, national and regional levels. Mainstreaming these strategic priorities and policies into action on the ground is a key challenge from 2014 onwards. We also need to acknowledge that our scientific understanding of the issues, and our associated data and tools, also need to adapt and evolve to meet the challenges of not just climate change, but the many other environmental and socio-economic objectives required for sustainable development. The framework, analyses and assessments presented herein, are potentially valuable tools for targeting limited resources to achieve desirable outcomes. They are also flexible and have scope to be improved and updated in the future, such as incorporating improvements in scientific understanding and utilising higher resolution data as it becomes available. In so doing it will facilitate a better understanding of the climate change challenges we face and support the formulation of solutions to optimally address those challenges. 


\section{Acknowledgements}

This work has been funded by the European Commission (DG Climate Action) as part of a wider research project (Ref. 071201/2011/609681/SER/CLIMA.A.2). The Commission's support is gratefully acknowledged. The opinions expressed herein are those of the authors and not necessarily those of the funding body.

\section{References}

Adger WN (2006) Vulnerability. Global Environmental Change 16: 268-281

Balmford A, Fisher B, Green RE, Naidoo R, Strassburg B, Turner RK, Rodrigues ASL (2011) Bringing Ecosystem Services into the RealWorld: An Operational Framework for Assessing the Economic Consequences of Losing Wild Nature. Environmental and Resource Economics 48: $161-175$

Bellard C, Bertelsmeier C, Leadley P, Thuiller W, Courchamp F (2012) Impacts of climate change on the future of biodiversity. Ecology Letters 15(4): 365-377

Booij MJ (2005) Impact of climate change on river flooding assessed with different spatial model resolutions. Journal of Hydrology 303(1-4): 176-198

Brown PR, Nelson R, Jacobs B, Kokic P, Tracey J, Ahmed M, DeVoil P (2010) Enabling natural resource managers to self-assess their adaptive capacity. Agricultural Systems 103: 562568

Brūmelis G, Jonsson BG, Kouki J, Kuuluvainen T, Shorohova E (2011) Forest naturalness in northern Europe: perspectives on processes, structures and species diversity. Silva Fennica 45(5): $807-821$

Ciscar JC, Iglesias A, Feyen L, Goodess CM, Szabó L, Christensen OB, Nicholls R, Amelung B, Watkiss P, Bosello F, Dankers R, Garrote L, Hunt A, Horrocks L, Moneo M, Moreno A, Pye S, Quiroga S, van Regemorter D, Richards J, Roson R, Soria A (2009) Climate change impacts 
in Europe. Final report of the PESETA research project. European Commission, Joint Research Centre, EUR 24093 EN

Christensen JH, Christensen OB (2003) Climate modelling: Severe summertime flooding in Europe. Nature 421: 805-806

Christensen OB, Goodess CM, Harris I, Watkiss, P (2011) European and Global Climate Change Projections: Discussion of Climate Change Model Outputs, Scenarios and Uncertainty in the EC RTD ClimateCost Project. In Watkiss P (ed) The ClimateCost Project. Final Report. Volume 1: Europe. Published by the Stockholm Environment Institute, Sweden. ISBN 978$91-86125-35-6$

CLM-Community (2013) Climate Limited-area Modelling Community. http://www.clmcommunity.eu/. Cited 6 August 2013

Dawson TP, Jackson ST, House JI, Prentice IC, Mace GM (2011) Beyond Predictions: Biodiversity Conservation in a Changing Climate. Science 332(6025): 53-58

Dawson JJC, Smith P (2007) Carbon losses from soil and its consequences for land-use management. Science of the Total Environment 382: 165-190

de Groot RS, Wilson MA, Boumans RMJ (2002) A typology for the classification, description and valuation of ecosystem functions, goods and services. Ecological Economics 41: 393-408

de Groot RS, Alkemade R, Braat L, Hein L, Willemen L (2010) Challenges in integrating the concept of ecosystem services and values in landscape planning, management and decision making. Ecological Complexity 7: 260-272

EC (2011) Proposal for a Regulation of the European Parliament and of the Council on support for rural development by the European Agricultural Fund for Rural Development (EAFRD). European Commission (EC), $\operatorname{COM}(2011) 627$ final/2, 2011/0282 (COD), Brussels, 19.10.2011

EC (2012) Proposal for a Decision of the European Parliament and of the Council on a General Union Environment Action Programme to 2020 "Living well, within the limits of our planet". European Commission (EC), COM(2012) 710 final, 2012/0337 (COD), Brussels, 29.11.2012 
EC (2013) Communication from the Commission to the European Parliament, the Council, the European Economic and Social Committee and the Committee of the Regions. An EU Strategy on adaptation to climate change. European Commission (EC), $\operatorname{COM(2013)~} 216$ final, Brussels, 16.4.2013

EEA (2004) Elevation map of Europe. European Environment Agency (EEA). http://www.eea.europa.eu/data-and-maps/data/digital-elevation-model-of-europe. Cited 1 May 2012

EEA (2006) CORINE Land Cover 2006 raster data. Version 16 (04/2012): 2000 and 2006 combined. European Environment Agency (EEA)

EEA (2012) WFD: Surface Water

http://www.eea.europa.eu/themes/water/interactive/soe-wfd/wfd-surface-water-viewer.

Cited 1 May 2012

Ellis F (2000) Rural Development and Diversity in Developing Countries. Oxford University Press: Oxford, UK

Engle NL (2011) Adaptive capacity and its assessment. Global Environmental Change 21: 647656

ESPON (2012) Climate change may hamper territorial cohesion. EPSON 2013 Programme/Map of the Month January 2012. ESPON Programme, the European Observation Network for Territorial Development and Cohesion. www.espon.eu. Cited 2 April 2012

Eurostat (2012) Agriculture statistics at regional level. http://epp.eurostat.ec.europa.eu/statistics explained/index.php/Agriculture statistics at re gional level\#Further Eurostat information. Cited 31 May 2012

Foley AM (2010) Uncertainty in regional climate modelling: A review. Progress in Physical Geography 34(5): 647-670

Gallai N, Salles JM, Setelle J, Vaissiere BE (2009) Economic valuation of the vulnerability of world agriculture confronted to pollinator decline. Ecological Economics 68: 810-821

Haines-Young R, Potschin M (2010) Proposal for a Common International Classification of Ecosystem Goods and Services (CICES) for Integrated Environmental and Economic 
Accounting (V1). Report prepared by Centre for Environmental Management, University of Nottingham, United Kingdom for the European Environment Agency, Contract No: No. EEA/BSS/07/007

Helgason BL, Janzen HH, Chantigny MH, Drury CF, Ellert BH, Gregorich EG, Lemke RL, Pattey E (2005) Toward improved coefficients for predicting direct $\mathrm{N}_{2} \mathrm{O}$ emissions from soils in Canadian Agroecosystems. Nutrient Cycling in Agroecosystems 72: 87-99

Houghton JT, Ding Y, Griggs DJ, Noguer M, Van Der Linden PJ, Xiaosu D (eds) (2001) Climate Change 2001: The Scientific Basis. Cambridge University Press, Cambridge

IPCC (1990) The Intergovernmental Panel on Climate Change (IPCC) First Assessment Report 1990

IPCC (2001) The Intergovernmental Panel on Climate Change (IPCC) Third Assessment Report 2001

Jackson ST, Sax DF (2009) Balancing biodiversity in a changing environment: extinction debt, immigration credit and species turnover. Trends in Ecology and Evolution 25(3): 153-160

Jones RJA, Hiederer R, Rusco E, Loveland PJ, Montanarella L (2004) The map of organic carbon in topsoils in Europe. Version 1.2, September 2003: Explanation of Special Publication Ispra 2004 No.72 (S.P.I.04.72). European Soil Bureau Research Report No.17, EUR 21209 EN, 26pp. and 1 map in ISO B1 format. Office for Official Publications of the European Communities, Luxembourg

Jones RJA, Hiederer R, Rusco E, Loveland PJ, Montanarella L (2005) Estimating organic carbon in the soils of Europe for policy support. European Journal of Soil Science 56: 655-671

JRC (2012) Soil organic matter content GIS data. JRC European Soil Portal http://eusoils.jrc.ec.europa.eu. Cited 1 May 2012

Kirkby MJ, Jones RJA, Irvine B, Gobin A, Govers G, Cerdan O, Van Rompaey AJJ, Le Bissonnais Y, Daroussin J, King D, Montanarella L, Grimm M, Vieillefont V, Puigdefabregas J, Boer M, Kosmas C, Yassoglou N, Tsara M, Mantel S, van Lynden GJ, Huting J (2003) Pan-European 
Soil Erosion Risk Assessment: The PESERA Map. Version 1 October 2003. Explanation of: Special Publication Ispra 2004 No.73 S.P.I.04.73

Lindner M, Maroschek M, Netherer S, Kremer A, Barbati A, Garcia-Gonzalo J, Seidl R, Delzon S, Corona P, Kolström M, Lexer MJ, Marchetti M (2010) Climate change impacts, adaptive capacity, and vulnerability of European forest ecosystems. Forest Ecology and Management 259(4): 698-709

Louwagie G, Gay SH, Burrell A (2009) Sustainable Agriculture and Soil Conservation (SoCo). Final report. EUR 23820 EN - 2009. DG Agriculture and Rural Development, European Commission.

Marland G, McCarl BA, Schneider UA (2001) Soil carbon: policy and economics. Climate Change 51: 101-117

McCarthy JJ, Canziani OF, Leary NA, Dokken DJ, White KS (eds) (2001) Climate Change 2001: Impacts, Adaptation and Vulnerability. Cambridge University Press, Cambridge

McInnes RJ, Crane M, Rodda HJE, Danks PW, Hogan DV, Field AI (2008) Management of the Otmoor protected area (Oxfordshire) (Multifunctional wetlands in agricultural landscapes: An evaluation of values, impacts and the application of the ecosystem-based approach). WWT Report to Defra. Project Reference: NR0112. WWT, Slimbridge, UK

MEA (2003) Ecosystems and human well-being. A framework for assessment. Millennium Ecosystem Assessment (MEA), Island Press, Washington DC, USA

Moorby JM, Chadwick DR, Scholefield D, Chambers BJ, Williams JR (2007) A review of best practice for reducing greenhouse gases. Defra project report AC0206

Moss RH, Edmonds JA, Hibbard KA, Manning MR, Rose SK, van Vuuren DP, Carter TR, Emori S, Kainuma M, Kram T, Meehl GA, Mitchell JFB, Nakicenovic N, Riahi K, Smith SJ, Stouffer RJ, Thomson AM, Weyant JP, Wilbanks TJ (2010) The next generation of scenarios for climate change research and assessment. Nature 463: 747-756

Natural England (2011) A national climate change vulnerability assessment. Technical Information Note TIN095, Natural England, UK. 
Nelson R, Brown PR, Darbas T, Kokic P, Cody K (2007) The potential to map the adaptive capacity of Australian land managers for NRM policy using ABS data. CSIRO, Australian Bureau of Agricultural and Resource Economics, prepared for the National Land \& Water Resources Audit

Nelson R, Kokic P, Crimp S, Meinke H, Howden SM (2010a) The vulnerability of Australian rural communities to climate variability and change: Part I - Conceptualising and measuring vulnerability. Environmental Science and Policy 13: 8-17

Nelson R, Kokic P, Crimp S, Martin P, Meinke H, Howden SM, de Voil P, Nidumolu U (2010b) The vulnerability of Australian rural communities to climate variability and change: Part II Integrating impacts with adaptive capacity. Environmental Science and Policy 13: 18-27

NSRI (2001) A guide to better soil structure. National Soil Resources Institute, Cranfield University, Silsoe, Bedfordshire, MK45 4DT, UK

O'Brien K, Leichenko R, Kelkar U, Venema H, Aandahl G, Tompkins H, Javed A, Bhadwal A, Barg S, Nygaard L, West J (2004) Mapping vulnerability to multiple stressors: climate change and globalization in India. Global Environmental Change 14: 303-313

Owen J (2009) Sahara Desert Greening Due to Climate Change? National Geographic News. http://news.nationalgeographic.co.uk/news/2009/07/090731-green-sahara.html. Cited 31 July 2009

Pearson RG (2006) Climate change and the migration capacity of species. Trends in Ecology and Evolution 21(3): 111-113

Pindyck RS (2013) Climate Change Policy: What Do the Models Tell Us? National Bureau of Economic Research (NBER) Working Paper 19244, Cambridge, Massachusetts, USA

PNW (2010) Reducing Fire Risk on Your Forest Property. A Pacific Northwest (PNW) Extension Publication, PNW 618, October 2010, Oregon State University, University of Idaho, Washington State University, USA.

Potts SG, Biesmeijer JC, Kremen C, Neumann P, Schweiger O, Kunin WE (2010) Global pollinator declines: trends, impacts and drivers. Trends in Ecology and Evolution 25(6): $345-353$ 
Prudhomme C, Kay AL, Crooks S, Reynard N (2013) Climate change and river flooding: Part 2 sensitivity characterisation for British catchments and example vulnerability assessments. Climatic Change DOI: $10.1007 /$ s10584-013-0726-3

Reto K, Furrer R, Tebaldi C, Cermak J, Meehl GA (2010) Challenges in Combining Projections from Multiple Climate Models. Journal of Climate 23: 2739-2758

Rockel B, Will A, Hense A (2008) The Regional Climate Model COSMO-CLM (CCLM). Meteorologische Zeitschrift 17(4): 347-348

Schröter D, Acosta-Michlik L, Arnell AW, Araújo MB, Badeck F, Bakker M, Bondeau A, Bugmann $H$, Carter T, de la Vega-Leinert AC, Erhard M, Espiñeira GZ, Ewert F, Fritsch U, Friedlingstein P, Glendining M, Gracia CA, Hickler T, House J, Hulme M, Kankaanpää S, Klein RJT, Krukenberg B, Lavorel S, Leemans R, Lindner M, Liski J, Metzger MJ, Meyer J, Mitchell T, Mohren F, Morales P, Moreno JM, Reginster I, Reidsma P, Rounsevell M, Pla E, Pluimers J, Prentice IC, Pussinen A, Sánchez A, Sabaté S, Sitch S, Smith B, Smith J, Smith P, Sykes MT, Thonicke K, Thuiller W, Tuck G, van der Werf G, Vayreda J, Wattenbach M, Wilson DW, Woodward FI, Zaehle S, Zierl B, Zudin S, Cramer W (2004) Terrestrial Ecosystem Analysis and Modelling (ATEAM). Final report 2004, Section 5 and 6 and Annex 1 to 6 . Potsdam Institute for Climate Impact Research (PIK), Potsdam, Germany

Semenov MA, Stratonovitch P (2010) Use of multi-model ensembles from global climate models for assessment of climate change impacts. Climate Research 41: 1-14

Swanson DA, Hiley JC, Venema HD, Grosshans R (2009) Indicators of Adaptive Capacity to Climate Change for Agriculture in the Prairie Region of Canada: Comparison with Field Observations. Working Paper for the Prairie Climate Resilience Project, Winnipeg: International Institute for Sustainable Development

UNEP (2010) Global Honey Bee Colony Disorders and Other Threats to Insect Pollinators. UNEP Emerging Issues. United Nations Environment Programme (UNEP)

Vincent K (2007) Uncertainty in adaptive capacity and the importance of scale. Global Environmental Change 17: 12-24 
Vörösmarty CJ, McIntyre PB, Gessner MO, Dufgeon D, Prusevich A, Green P, Glidden S, Bunn SE, Sullivan CA, Reidy Liermann C, Davies PM (2010) Global threats to human water security and river biodiversity. Nature 467: 555-561

WMO (1979) WMO proceedings of the World Climate Conference: a conference of experts on climate and mankind. Geneva, 12-32 February 1979. World Meteorological Organisation (WMO) - No. 537. ISBN 92-63-10537-5 